\title{
Between Land and Sea: An Approach for Resilient Waterfront Development along the San Francisco Bay
}

\author{
Gabriel Kaprielian
}

ABSTRACT - The waterfront along the San Francisco Bay is facing a growing threat from sea-level rise. By the end of the century, a projected sea-level rise of $55 \mathrm{in}$. [140 cm] will affect an estimated $128 \mathrm{sq}$. mi. [331 $\left.\mathrm{km}^{2}\right]$ of urban development valued at $\$ 62$ billion. In addition, 2.1 million people and 660,000 homes are estimated to arrive by 2040, adding to the 7 million current Bay Area residents. Furthermore, sea-level rise will affect the ecology of the San Francisco Bay, threatening to submerge the majority of existing tidal wetlands by mid-century. To combat sea-level rise, many are calling for increased shoreline protection, while others suggest the removal of urban development in areas at risk of inundation, allowing tidal wetlands to migrate to higher elevations. In this proposal, I demonstrate that both may be accomplished by a managed retreat of existing development, enabling wetland migration, while introducing a resilient new typology of development built on levees that is designed to co-exist with a tidal ecosystem, enabling new relationships between urban life and bay ecology that redefine the coastal boundary.

Keywords: coastal resilience, ecology, managed retreat, sea-level rise, wetlands

The research in this article will introduce the issues associated with sea-level rise in the San Francisco Bay Area by presenting analysis on the implications for the built and natural environment. This will be followed by plans for a combined managed retreat and resilient redevelopment to address issues of sea-level rise, wetland ecology, and population growth. Such discussion will include a description of site analysis techniques, design methodology, and 
proposed development strategies. The conclusion will offer a reflection on the design process and outcomes.

\section{THE IMPACT OF SEA-LEVEL RISE ON THE BAY AREA}

Two state-sponsored studies of sea-level rise impact on the Bay Area were used extensively in preparing my research: the San Francisco Bay Conservation and Development Commission's (BCDC) "Living with a Rising Bay: Vulnerability and Adaptation in San Francisco Bay and on its Shoreline" (2011), and the Pacific Institute's "The Impact of Sea Level Rise on the California Coast" (2009). These reports represent a robust analysis of projected implications for urban development and bay ecology due to rising sea levels. They constitute a wealth of data quantifying sea-level rise impacts and serve as advisory information for potential adaptive strategies.

A vulnerability assessment by BCDC uses two sea-level rise projections: a 16 in. [40 cm] sea-level rise by mid-century and a 55 in. [140 cm] rise in sea level by the end of the century. Their study puts 281 sq. mi.

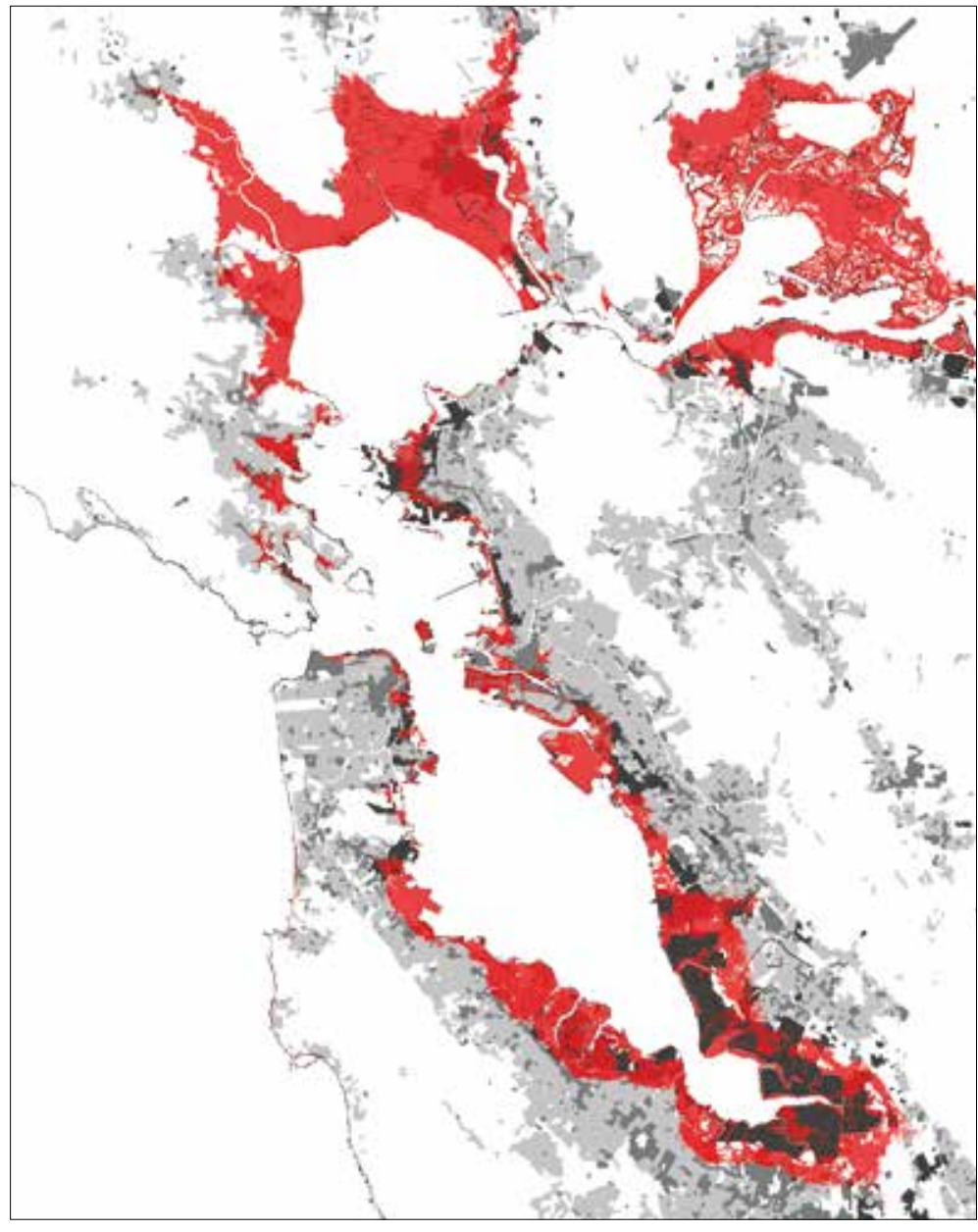

MAP KEY

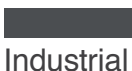

Industrial

Commercial

Residential

$140 \mathrm{~cm}$

Sea-Level Rise

Figure 1.

Composite

map illustrating

impact of 59 in

[140 cm] SLR

on land use. 
[728 km²] of Bay shoreline at risk of flooding from 16 in. [40 cm] of sea-level rise, and $333 \mathrm{sq}$. mi. [862 km²] at risk from a $55 \mathrm{in} .[140 \mathrm{~cm}]$ sea-level rise. A 55 in. [140 cm] rise in sea levels would place an estimated 270,000 people around the Bay Area at risk, constituting over half of the projected population affected in the entire state. The Pacific Institute further elaborates on these metrics by describing how communities of color and low-income populations will be disproportionately affected, ${ }^{1}$ while critical infrastructure and "vast areas of wetlands and other ecosystems" will be at increased risk of inundation. ${ }^{2}$

The report by BCDC also places significant portions of the bay ecosystem in peril with rising sea levels. A sea-level rise scenario of $16 \mathrm{in}$. [40 cm] is "sufficient to impact 90 to $95 \%$ of the existing tidal marshes." ${ }^{3}$ With decreased sediment flowing from the Delta, it is uncertain whether tidal wetlands would be able to migrate with rising sea levels. Static coastal management structures further complicate the future existence of tidal wetlands, creating a barrier for upland migration with the potential consequence of submersion.

Bay Area Urban Development 140cm Sea Level Rise

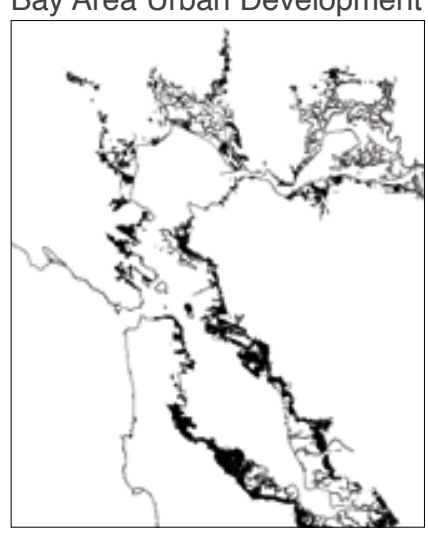

Urban Development Affected by $140 \mathrm{~cm} \mathrm{SRL}$

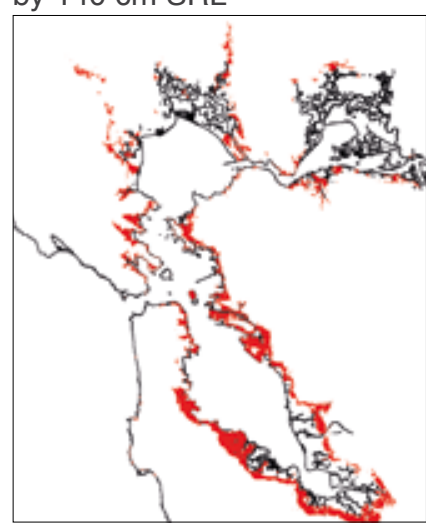

Historic Wetlands

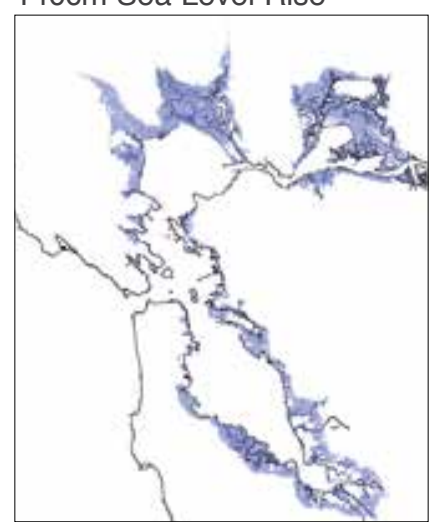

Projected Wetlands at $140 \mathrm{~cm} \mathrm{SRL}$

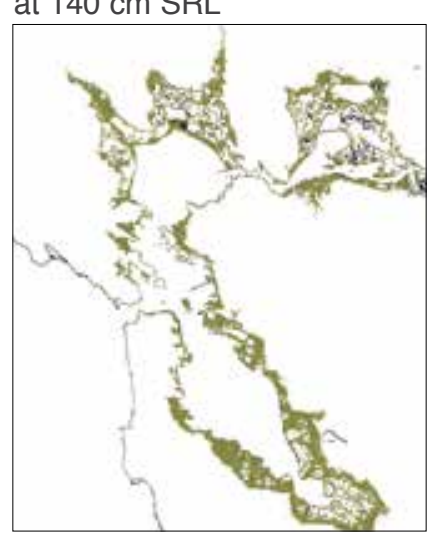

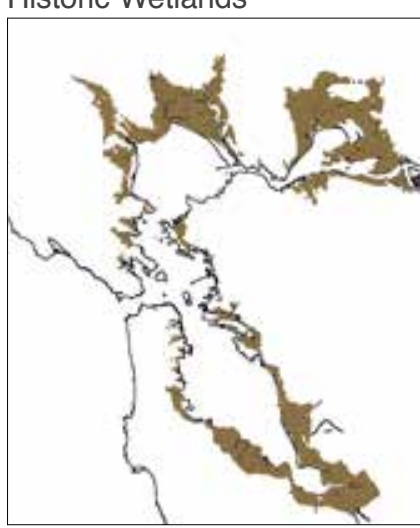

Bay Fill Development

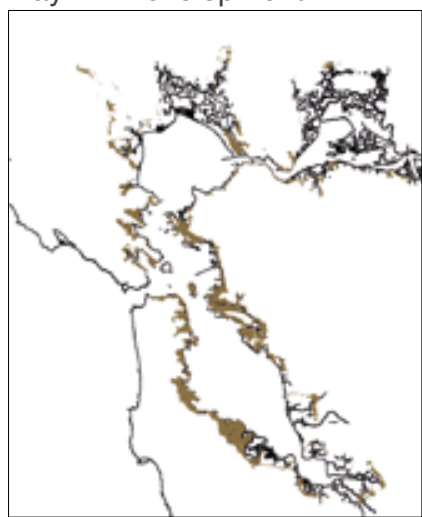

Figure 2. Mapping analysis of the San Francisco Bay Area development built on bay fill and historic tidal wetlands. 


\section{THE CASE FOR PRESERVING SAN FRANCISCO BAY TIDELANDS}

A "2013 National Climate Assessment on Coastal Impacts, Adaptation, and Vulnerabilities" states that a functioning coastal ecosystem is essential to all of the economically important sectors by "providing an environment that sustains natural habitats and resources for use by communities." 4 The interdependence of cities and their surrounding ecosystem often goes unnoticed in this age of inter-global trade and regionally connected infrastructure. The field of ecology has demonstrated that however detached people may feel from their surroundings, the intricate web of life connects human action with the natural environment, which in turn supports our very existence.

As the largest estuary along the Pacific shore of North America, the San Francisco Bay is an important and unique ecosystem. The defining characteristic of the Bay is the tidal wetlands, habitat for millions of migrating birds yearly. The tidal wetlands also provide flood protection and improve water quality through natural filtration of pollutants and shoreline stabilization, while also serving a vital role as a source of carbon sequestration. In his book, Down by the Bay: The History of San Francisco Between the Tides, Matthew Booker declares that "acre for acre, tidal wetlands convert more sunlight, air, and water to plant matter and animal flesh than any grassland or tropical rain forest." ${ }^{5}$

Over $80 \%$ of the tidal wetlands in the San Francisco and San Pablo Bay have been filled or modified since the late nineteenth century. ${ }^{6}$ The sealevel rise projections for the mid and end of the century, in combination with proposed levees for coastal armament, will all but wipe out the remaining tidelands. On the other hand, if given the opportunity, tidal wetlands may be able to migrate with rising sea levels, returning to their historic location and expanding inland. To accomplish an inland migration with the rising tides, wetlands build soil by trapping mineral sediment carried by tidal waters and accumulation of plant matter. Under moderate projections of sea-level rise, simulations show that coastal marshes would likely survive if there were adequate upland area with which to migrate. ${ }^{7}$

\section{SEA-LEVEL RISE MITIGATION STRATEGIES}

Many people regard sea-level rise as a far off threat, since it appears to be advancing slowly. The Bay Area lacks the type of storms recently seen in New York, New Orleans, and Houston that have caused massive damage; further adding to a public perception that sea-level rise is not a pressing issue. However, a comprehensive plan to address the complexity of rising tides in the Bay Area will need to be implemented before major problems occur if the desire is to do more than put a bandage on the current outdated infrastructure. This will require an orchestrated effort between Federal, State, and local governments around the San Francisco Bay, including the participation and support of residents and various stakeholders. 
The decisions that are made, including non-action, will have a rippling effect on the future trajectory of the Bay Area for generations to come.

A report by the coastal zone management subgroup of the IPCC divided available sea-level rise response options into three groups, with the following definitions: ${ }^{8}$

1. "Retreat - abandon structures in currently developed areas, resettle the inhabitants, and require that any new development be set back specific distances from the shore, as appropriate."

2. "Accommodate - continue to occupy vulnerable areas, but accept the greater degree of flooding (e.g. convert farms to fish ponds)."

3. "Protect - defend vulnerable areas, especially population centers, economic activities, and natural resources."
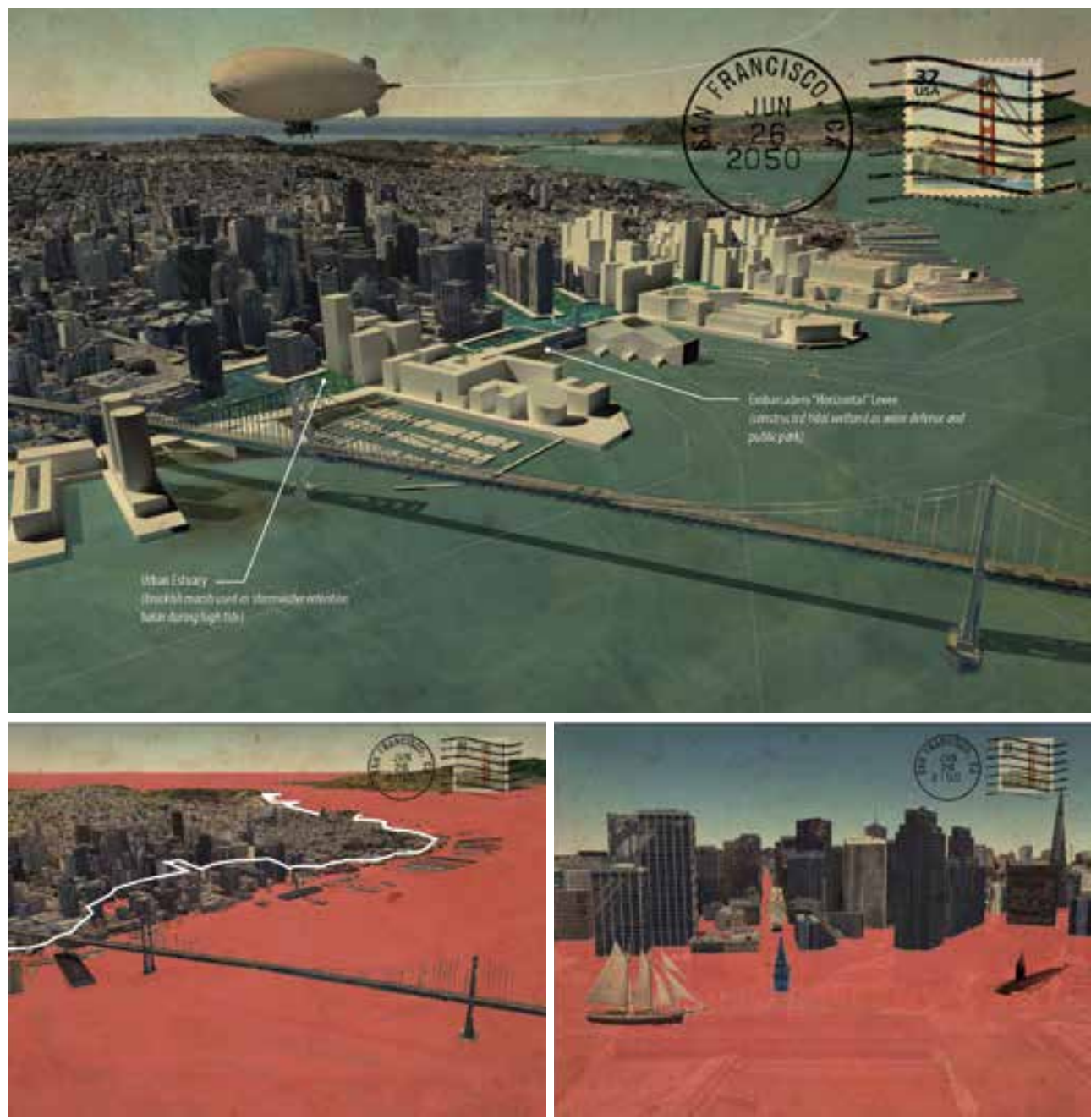

Figure 3. San Francisco visions of the future (counterclockwise from top), 2050 plan for resilient shoreline, 2100 projected sea-level rise inundation, 2150 visualization of extreme sea-level rise. 
The question of "retreat," "accommodate," or "protect," is at the core of the sea-level rise debate. However, this separation of words into categories both mirrors and perpetuates the entrenchment of advocacy groups into a singular view of the issue. By contrast, a mitigation strategy may incorporate all three sea-level rise options, or variations of each. Giving a word or phrase the title of an entire strategy serves to polarize groups and box in options. This is key to the debate of "levee vs. wetlands."

Fight or flight is one way the debate has narrowed into a strategy of protection of property or protection of the environment. This pits property owners versus environmentalists. While an emotional topic for both parties, much of the debate will hinge on economic forces that will likely come from many places. If larger levees are to be built or city boundaries pulled back to accommodate rising tides, this will require massive funding that local government would be unable to afford, requiring help from federal and state agencies.
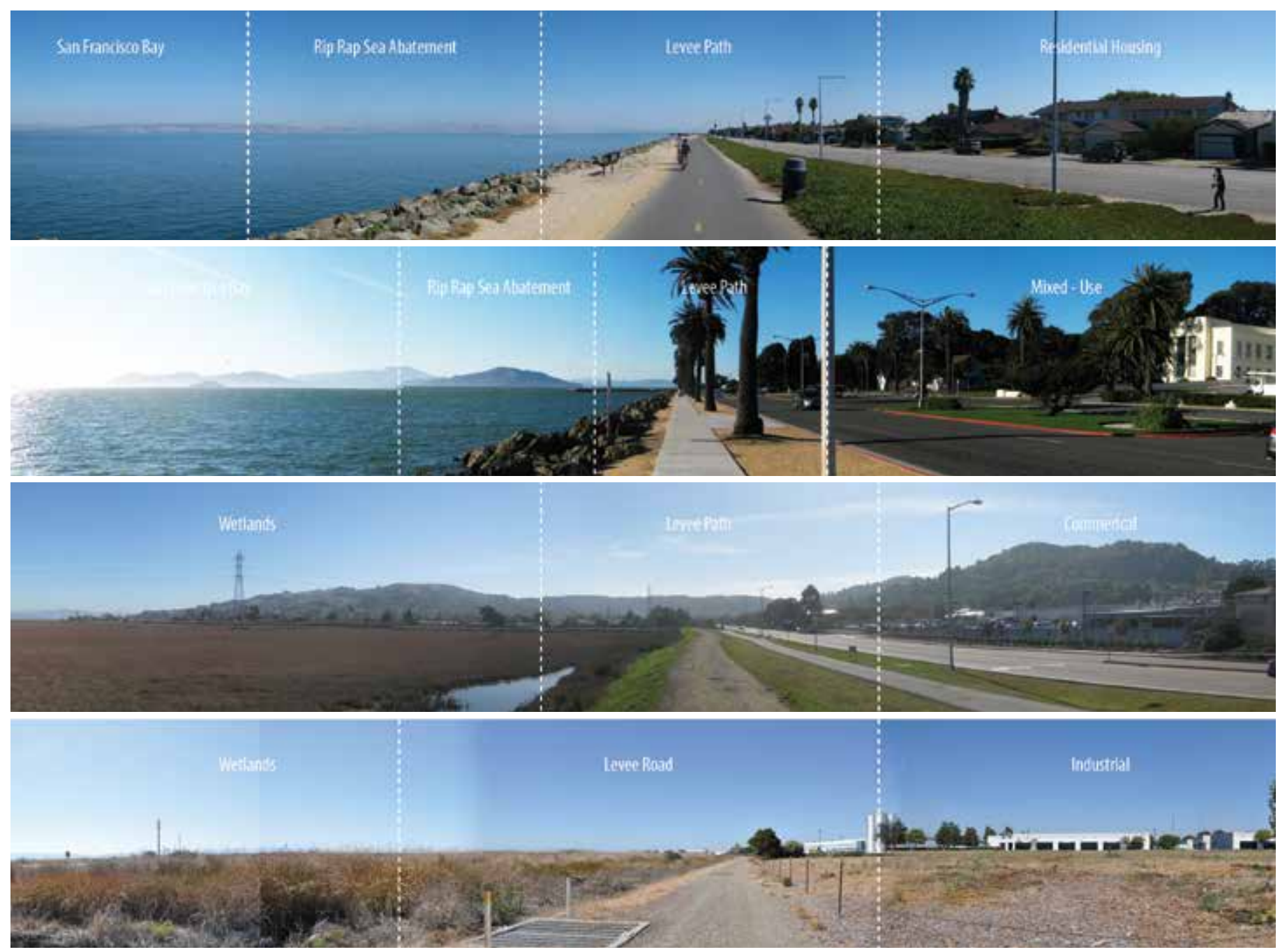

Figure 4. Waterfront typology study of the San Francisco Bay. 
The question of protection versus relocation is ultimately a question of value. Will it be worth building sea abatement structures if high-risk areas continue to be vulnerable to rising sea levels? Are the remaining tidal wetlands in the San Francisco Bay a valued asset that outweighs the cost of a managed retreat? Currently, land that is protected by a levee, but below sea level is not considered at risk of flooding by insurance assessment. ${ }^{9}$ This is almost sure to change in the future as cost outweighs the benefit of selling insurance in areas of high risk. What then will be their fate?

When talking about a managed retreat strategy, eminent domain is the elephant in the room. This phrase conjures up a myriad of responses that relate to the people that will be displaced, the logistics of how it will be accomplished, and the money that it will cost. A BCDC report states that with a sea level rise of 55 in. [140 cm], $98 \%$ more people will be at risk. According to the report, by the middle of the century, and likely earlier, "residents, businesses and entire industries that currently thrive on the shoreline are subject to flooding." ${ }^{10}$ Approximately 103 sq. mi. [267 km²] of residential development will be subject to $100 \%$ chance of flooding by mid-century, with over $128 \mathrm{sq}$. mi. [332 $\mathrm{km}^{2}$ ] vulnerable to flooding by the end of the century. The total assessed economic value of Bay Area shoreline development at risk of flooding from $55 \mathrm{in.}$ [140 cm] sea-level rise is estimated at US\$62 billion, accounting for two-thirds of vulnerable property in California.

Ultimately, economic cost will play a driving force in determining managed retreat viability. By simply removing current urban development and replacing it with tidal wetlands, there are no immediate earnings to offset what will be staggering costs. These costs include the relocation of public infrastructure, compensation for private property, removal and disposal of current urban development; in effect, undoing the short sighted "progress" since the mid-twentieth century.

Examining the issues of sea-level rise on Bay Area development, it becomes apparent that conventional solutions will not solve the problems that we face. Neither the building of more levees nor a managed retreat alone offers a viable plan to address the issue of sea-level rise. I propose that it is time that we consider other options that combine protection and relocation with design. By reframing sea-level rise as an "opportunity" rather than as a "problem," we have a chance to redesign the Bay Area waterfront to be a model of sustainability for the twenty-first century. Through the incorporation of resilient and adaptable design strategies, we can aim for a new development that is environmentally, economically, and socially sustainable. 


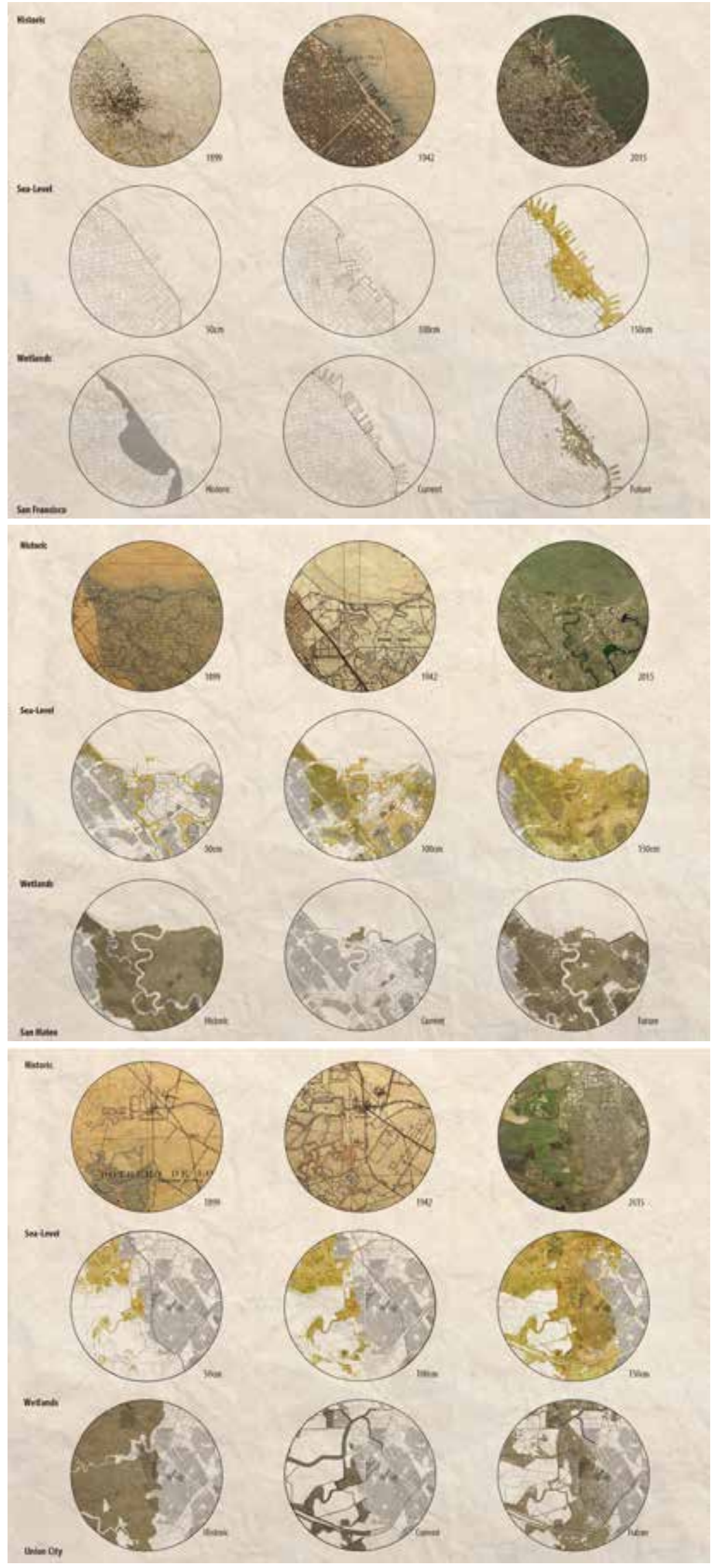

Figure 5. Site analysis (from top to bottom) San Mateo, San Francisco, Union City. 


\section{SITE ANALYSIS}

The site analysis process involved an examination of the past and present built and natural environment and future sea-level rise scenarios. Analysis began by examining the historic context of each site. Starting first with mapping, geo-referenced historical maps were overlaid with maps of the present built and natural environment. These composite maps were used for the purpose of investigating historical ecology and urban morphology, to uncover the pre-development conditions and site transformations. I utilized historical ecology as a framework to better understand the native ecosystem around the San Francisco Bay, thereby informing an approach for a managed retreat, wetland restoration, and re-development strategy in response to sea-level rise. Research of site history through photographs and text supplemented a mapping analysis.

The San Francisco Estuary Institute defines historical ecology as:

"Synthesizing diverse historical records to learn how habitats were distributed and ecological functions were maintained within the native California landscape. Understanding how streams, wetlands, and woodlands were organized along physical gradients helps scientists and managers develop new strategies for more integrated and functional landscape management." 11

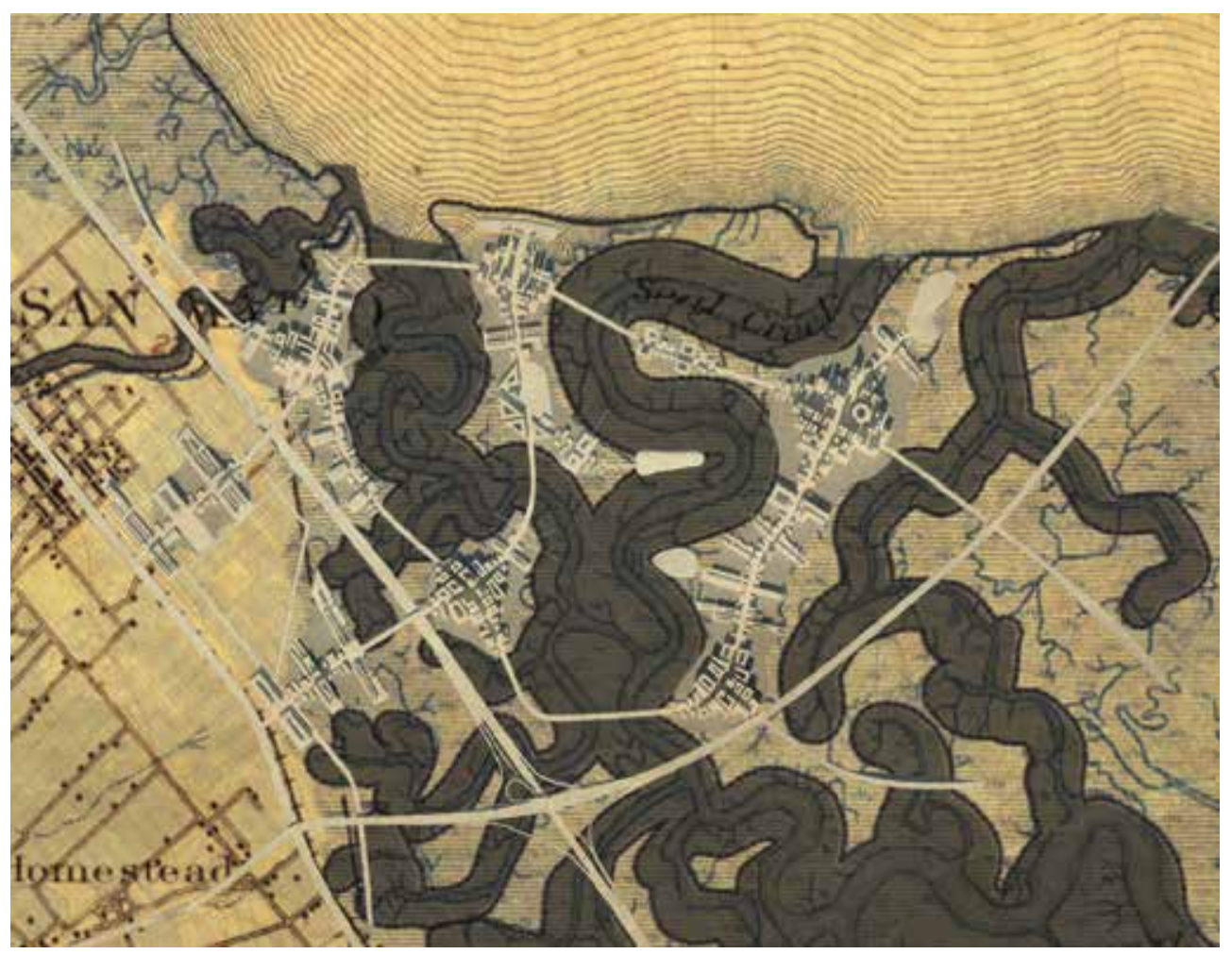

Figure 6. Suitability analysis - historical waterway buffer (San Mateo). 
The 1852 U.S. Coastal Survey and the 1899 and 1942 USGS maps served as my primary historic map references. Geo-referencing these maps in ArcGIS allowed for the overlay of current layers of infrastructure for further analysis, therefore enabling a comparison between historic conditions and those of the present built and natural environment. A look at historic maps of the nineteenth and twentieth century around the San Francisco Bay, in combination with archived accounts and detailed descriptions, paints a vivid portrait of the native landscape along the Bay. This knowledge was used in determining not only what the coastline looked like in the past, but also how it can be restored in the future.

By overlaying sea-level rise maps onto historic maps, it was evident that the San Francisco Bay water is once again reclaiming the land that had been filled for development. Visualizing the superimposition of historic creeks and sloughs with projected inundation areas from rising sea levels speaks to the dormant nature of the native landscape that exists beneath our cities. This realization led to my use of historical ecology as a driving force in the design process. In this way, the native landscape and existing development act as collaborators in the design of a managed retreat, wetland restoration, and adaptive re-development.

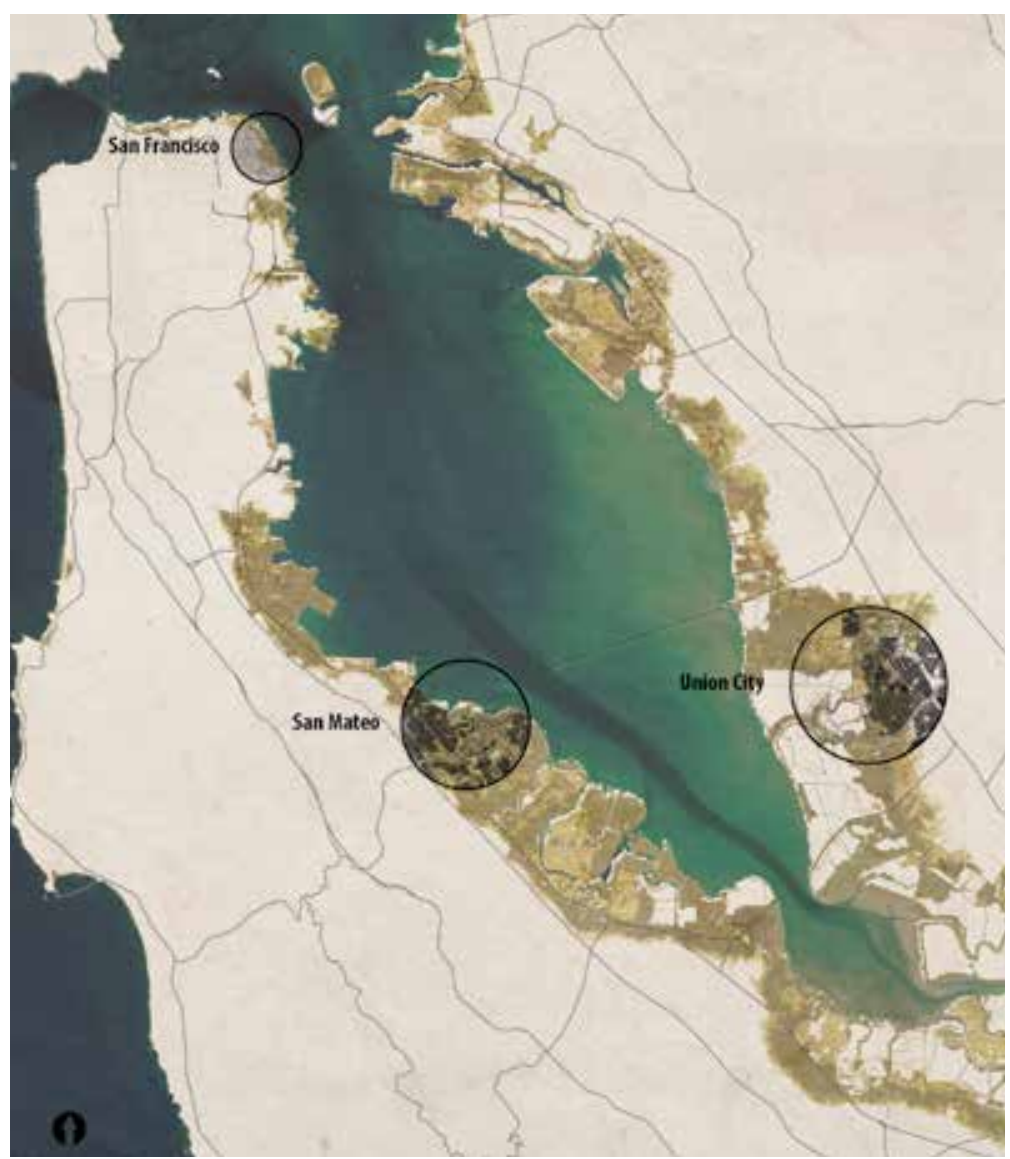

Figure 7. Regional site map (counterclockwise from top) San Francisco, San Mateo, Union City. 


\title{
SITE SELECTION
}

For my study, I choose three sites located along the urbanized waterfront of the San Francisco Bay Area. Each of these sites was chosen as representative of unique urban and ecological characteristics to serve as a model for similar areas around the Bay Area.

To locate these sites, I began through a data-driven mapping process. I collected data on sites that contained urban development at risk of sealevel rise, development built on bay fill, and historic or current wetlands. An addition to the original query explored the amount the potential area of wetland migration with sea-level rise, while analyzing the quantity that overlapped with current urban development.

The three sites that were chosen include:

\author{
San Francisco - Downtown (San Francisco County) \\ East San Mateo - Peninsula (San Mateo County) \\ Union City - East Bay (Alameda County)
}

A radial buffer of differing sizes bounds each site. The rationale for the site buffer was to frame particular locations with an area large enough to study the implications of sea-level rise projections of $20 \mathrm{in}$. [50 cm], 39 in. [100 cm] and 59 in. [150 cm], while also containing the current tidal ecosystem and infrastructure. The site boundaries do not indicate where a staged retreat and re-development would stop, but rather imply that it would continue along the coastline in a similar manner to adjacent sites as an interconnected network.

The goal of choosing varying sites was to test the proposed methodology of site analysis, managed retreat, and redevelopment strategy, thereby highlighting the contribution of the unique site characteristics in the design process. The factors of historical ecology, urban morphology, existing infrastructure, building density, and sea-level rise all play an important role in determining the design and urban form of future development. In this way, the site acts as a collaborator in the design process. It should be noted that the San Francisco site that was chosen was an outlier in a number of respects. While the area of downtown San Francisco was built on bay fill and is at risk of sea-level rise, it is a natural deep-water port and therefore did not contain significant tidal wetlands like the San Mateo and Union City sites.

\section{SITE DEVELOPMENT STRATEGIES: MANAGED RETREAT}

It is likely that a retreat of the current urban development will be required for the continued survival of the tidal wetlands around the Bay Area if sea levels rise as projected. Much of the current development was built on bay fill in areas of historic marshes. However, the uncertain timeline of sea-level 


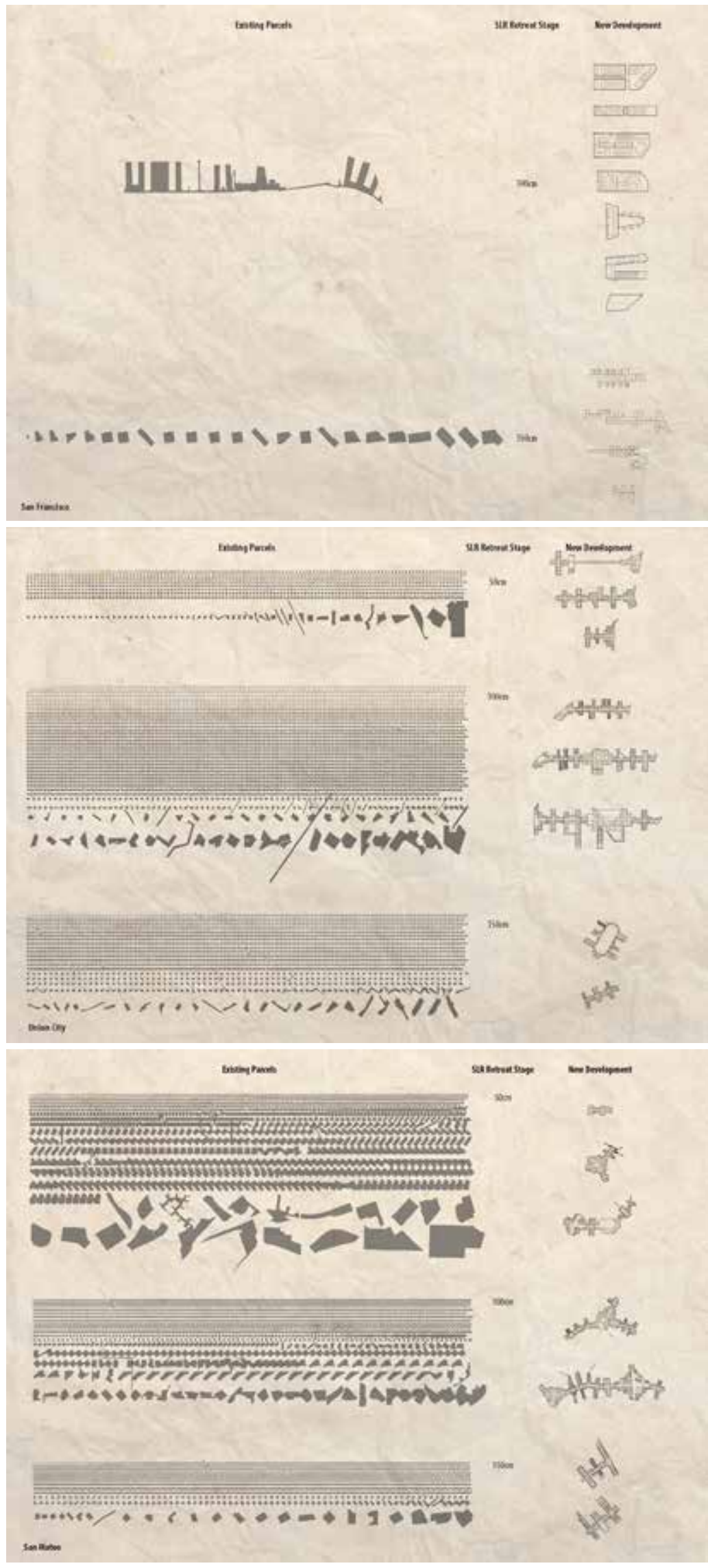

Figure 8.

Managed retreat plan - parcel removal and replacement with resilient new development (from top to bottom) San Mateo, San Francisco, Union City. 
rise creates an added layer of complexity in determining a retreat strategy. The solution is to create a managed retreat strategy that is site specific.

A managed retreat would open land currently occupied by urban development to intertidal action. The land would need to be prepared by removing buildings, roads, levees, and other infrastructure to allow tidal wetlands to migrate with rising Bay tides. The size and location of the land that would be cleared could be careful assessed by the risk of flooding posed at different stages of sea-level rise. I propose using the benchmark sea-level rise stages of $20 \mathrm{in}$. [50 cm], 39 in. [100 cm] and 59 in. $[150 \mathrm{~cm}]$.

By modeling inundation at different stages of sea-level rise, I identified the urban areas most at risk of flooding. For protection in cases of extreme flooding a levee perpendicular to tidal action would need to be placed at the new urban edge that defines the extent of the staged retreat. The location of this new levee should optimally be made near the edge of the inundation risk area for a given sea-level rise stage, while corresponding to current infrastructure.

Major roadways, including highways, arterial roads, and train track right of ways provide an ideal linear infrastructure location for the new levee. Many of the highways and train tracks along the Bay are at risk of inundation as the sea level rises. Since protective levees will need to be built at higher elevation and run parallel to the coastline, existing linear infrastructure presents an opportunity to have a continuous barrier for extreme flood conditions. This is illustrated in the San Mateo plan where the managed retreat levees are located on Highway $101(39 \mathrm{in} .[100 \mathrm{~cm}]$ $\mathrm{SLR}^{12}$ ) and the Cal Train tracks (59 in. [150 cm] SLR).

The new levees that run parallel to the coastline are designed to protect development at low risk of inundation with the express purpose of migrating to a new location further inland, corresponding to the edge of the next stage of retreat and transportation infrastructure location. The old levee will then be opened to tidal action when existing urban development has been cleared in the interstitial area upland of the old levee.

The managed retreat of urban development allows for the continued migration of tidal wetlands with the rising sea levels and has minimal dependence on human-made sea barriers to protect against flooding. The tidal wetlands, in turn, offer a natural barrier against storm surges, further protecting urban development.

\section{SITE DESIGN STRATEGIES: RESILIENT REDEVELOPMENT}

By redeveloping in the managed retreat area, a public-private partnership can be used to finance the use of eminent domain, the relocation of infrastructure, construction of levees, and the building of new development 

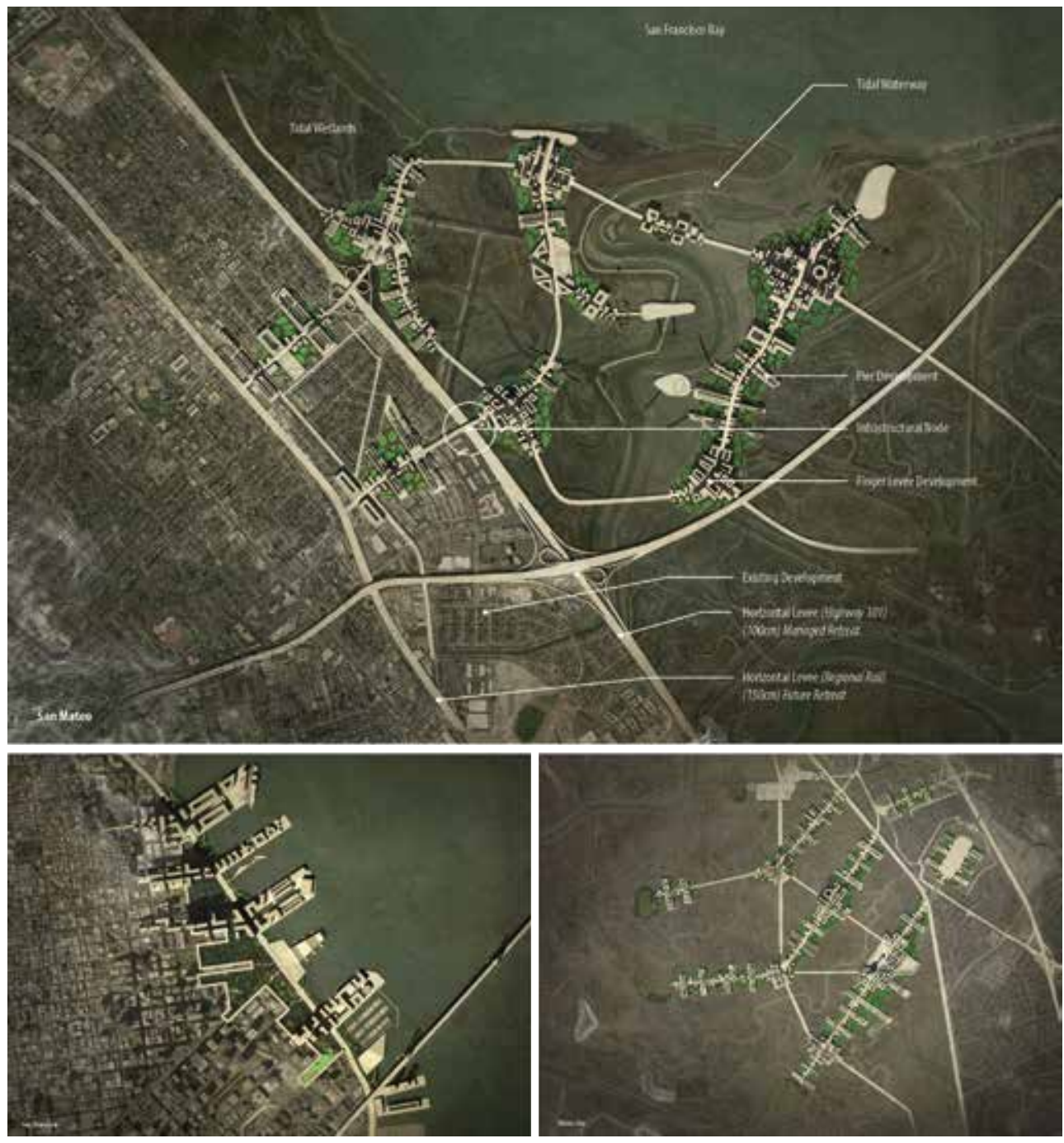

Figure 9. Redevelopment strategy at $39 \mathrm{in.}[100 \mathrm{~cm}$ ] sea-level rise (counterclockwise from top) San Mateo, San Francisco, Union City.

to house the growing population. This will need to be a new type of development that is built to coexist with rising sea level and the tidal wetlands. The footprint of the new built environment will be required to be drastically smaller and significantly denser to allow ample open space for tidal wetlands and housing. The proposal presented here consists of building a new resilient form of coastal development on what I call "Finger Levees."

The Finger Levee is the infrastructural backbone for the adaptive redevelopment strategy. In each of the three sites, the Finger Levee development replaces existing development that has been removed after a managed retreat. This involves the use of eminent domain to clear existing development at risk of inundation from sea-level rise and replaces it with new development on levees and piers, while leaving the majority of the land open for tidal action and wetland habitat. 
The Finger Levee design aims to create an adaptive and resilient new development that coexists with tidal wetland ecologies in a mutually beneficial relationship. The success of the Finger Levee development starts with the use of historical ecology and urban morphology to determine the most suitable land for development. The natural environment and existing infrastructure act as collaborators in the design process, informing the location and determining the shape of the Finger Levee development. The densification of the urban footprint and spacing between Finger Levee developments are important design attributes that allow for a healthy tideland to co-exist adjacent to the urban context. The centralized infrastructure of the Finger Levee, in addition to building development on pier foundations and closed-loop systems, create a resilient and sustainable model for waterfront development along the San Francisco Bay coastline.

\section{Development Pattern}

The pattern of Finger Levee development is determined by a combination of historical ecology and existing infrastructure for each site. The first step is to map the past ecological conditions of the site. To determine the most suitable land for future development, historic maps were used to identify the most solid land, which was located a sufficient distance from historic and existing sloughs, creeks, and bogs. This involved the creation of a system of buffers around such historic and existing water bodies with a distance that was determined by a safety factor of their ability to flood adjacent land.

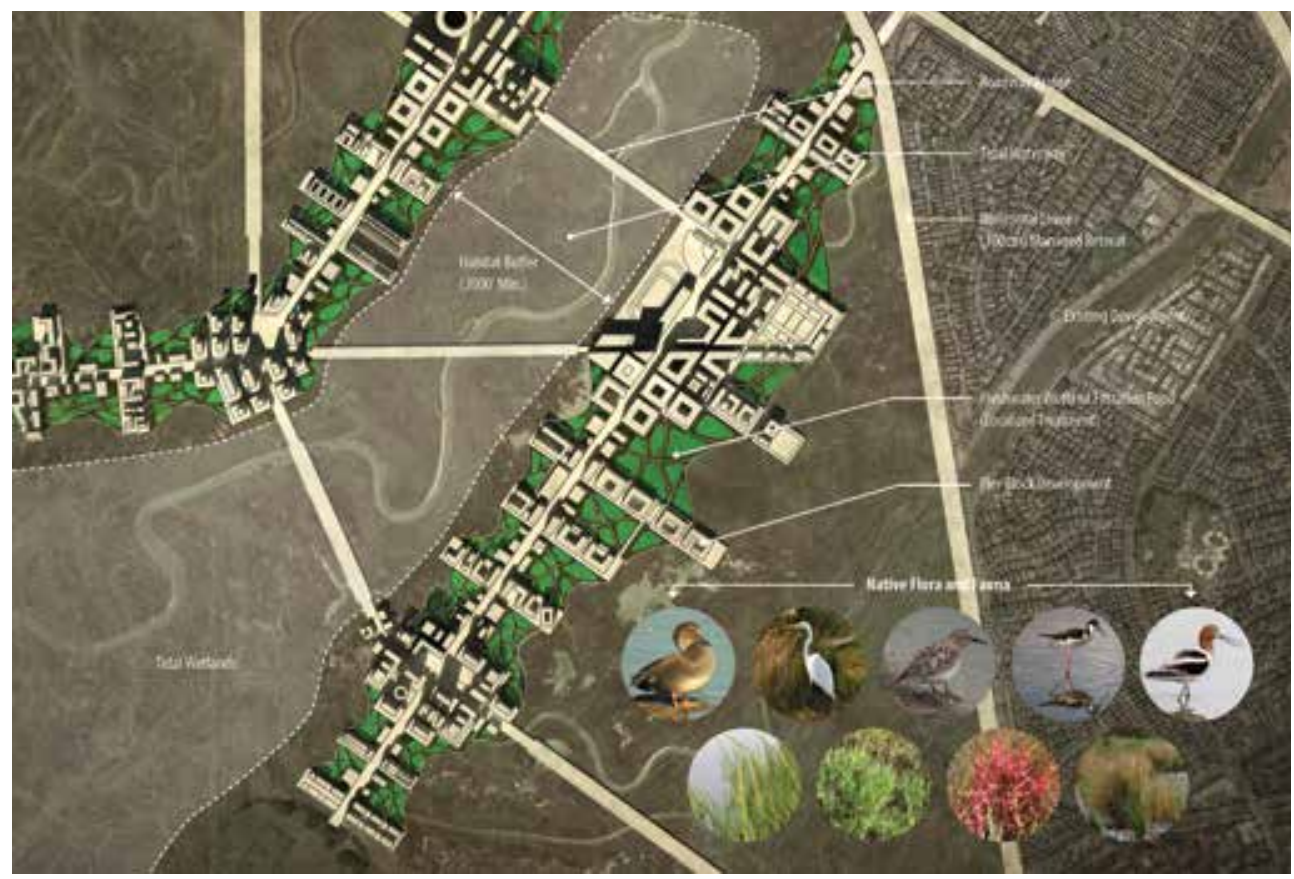

Figure 10. Finger levee development pattern - wetland habitat buffer (Union City). 
The area between the buffers made up the proposed buildable land.

The next step in determining the pattern of the Finger Levee development was to create a minimum buffer distance between the pier developments on side of the levee roadways. Buffer distance between Finger Levee developments was determined based on criteria for tidal wetland health and research on bird nesting habitat requirements. The Finger Levee roadways were designed to be parallel to tidal action or bridge over tidal input into interstitial wetlands, allowing for an unobstructed connection between wetlands and bay influence. Ample space was given with a development buffer around sloughs to allow wetland growth and sediment accretion.

A minimum of $2,000 \mathrm{ft}$. [610 m] was used as the spacing between Finger Levee developments for bird nesting habitat. This follows research on minimum requirements for a buffer around bird nesting in tidal wetlands. The buffer distance references a study that recorded the distance at which various birds were startled and flew away, thereby creating stress and leaving their nest, resulting in less offspring successfully raised. ${ }^{13}$ While each bird type had different requirements for buffer distance, the median distance according to Ruddock and Whitfield was between $500 \mathrm{ft}$. [152 m] and 1,000 ft. [305 m] - the San Francisco site differed from the other two sites based on the density of urban development and difference in environmental conditions and therefore used a 1,000 ft. [305 m] buffer.

The last step in laying out the Finger Levee roadways is the connection to existing infrastructure. Similar to an appendage that is being reattached, bone, arteries, and ligaments must be connected to the body. In this case, existing major roadways were identified as a connection "node" to the Finger Levee development, serving as a point of contact for vehicular transportation, energy, waste, and water infrastructure between the new and old urban landscapes. The Finger Levee operates as a centralized road infrastructure, connecting back to the existing urban fabric. All new infrastructures would be raised with the levee and pier development and protected from inundation and future flooding. Sustainable infrastructural initiatives in the urban design include "Transit-Oriented Development" (TOD), localized water and waste treatment and reuse facilities, and net-zero energy use with co-generation and other clean energy sources.

As a centralized road network, the Finger Levee acts as a natural TOD, combining efficient and accessible public transit. The design of the Finger Levee roadway is similar to that of a boulevard. A public transportation "Light Rail" (LTR) or "Bus Rapid Transit" (BRT) runs through the center lane with vehicular lanes on either side. A separated bicycle lane runs throughout the levee roadways, with generous tree-lined sidewalks on 


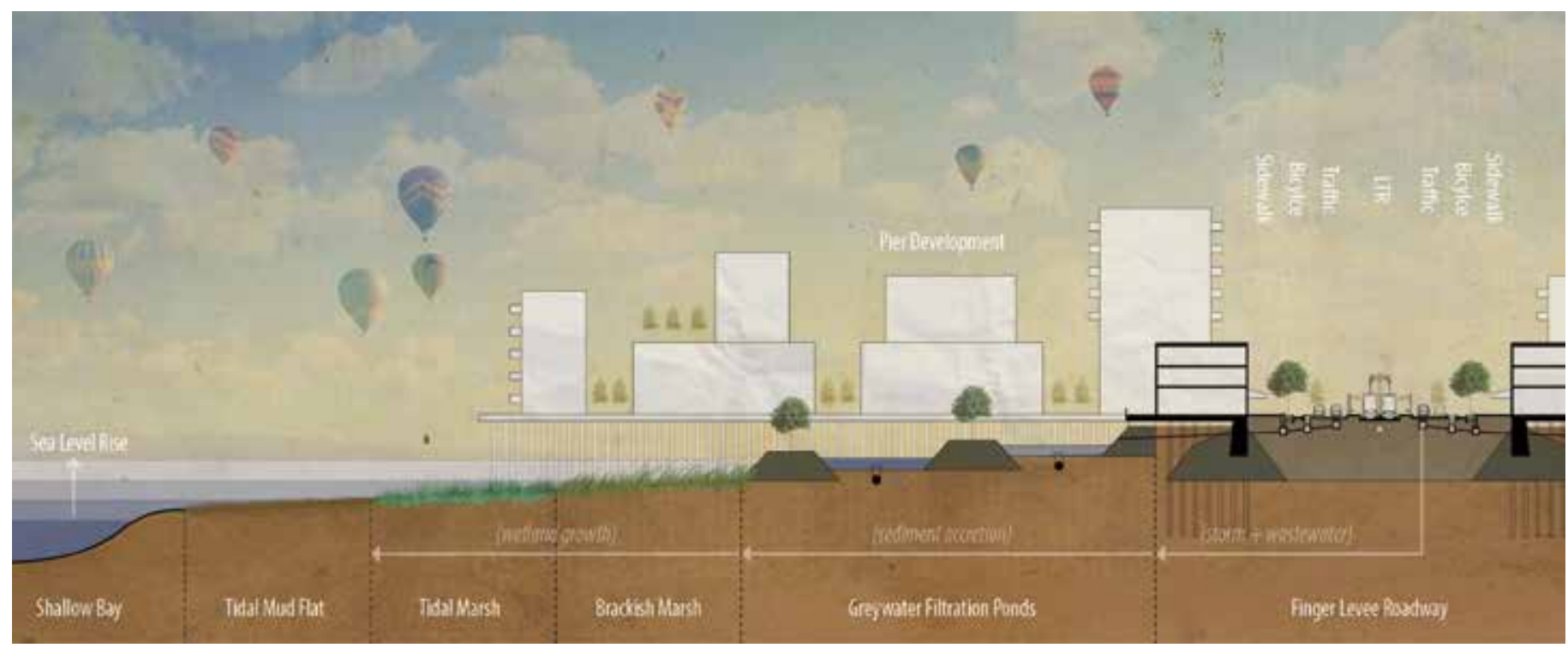

Figure 11. Typical section of finger levee development.

either side giving ample space for outdoor seating, landscaping, and public events.

Localizing water and waste treatment facilities create a sustainable development model for the Bay Area. Recent water and energy shortages in California have demonstrated the need to be more efficient with resources that will only become scarcer in the coming decades. The current drought has shown the unpredictability of water reserves in the arid western United States. Since most of the wastewater treatment facilities around the Bay are located along the waterfront, the majority of facilities are at risk of damage from sea-level rise. This will require substantial retrofitting or a complete rethinking of facility operations and redesign.

The proposal includes the creation of much smaller, localized treatment facilities that use freshwater wetland filtration ponds and utilize waste material co-generation energy plants that double as a tidal wetland sediment source. Water can then be recycled back into circulation through adjacent water purification plants. To create energy independence will require a combination of co-generation from waste, PV panels on rooftops, and wind generation where appropriate.

Material to build the raised Finger Levee roadway will be sourced from rubble in the staged retreat of the existing development, including asphalt and concrete from roads, parking areas, and building structures. Since the Finger Levee will account for less than $10 \%$ of the previous urban footprint, the rubble extracted from the development that is removed, including materials from buildings and roadways, will allow for a height well above sea-level rise projections. 


\section{Pier Development}

All buildings in the resilient redevelopment plan will be constructed on piers adjacent to the levee roadway. The rationale for this strategy is two fold; there is not enough rubble from existing development to create the additional levee foundations under buildings as well as roadways and the pier construction typology has less impact than fill on the tidelands environment. Furthermore, water can flow unabated between pier piling to wetlands on either side of pier block development.

Urban blocks will be constructed on raised piers attached to the Finger Levee roadway. Continuous pier development would line the sides of the levee roadway, while larger pier blocks can be built perpendicular to the levee road. The pier development that runs parallel to the levee should contain mostly commercial business on the ground level, with office and residential above. The property along the Finger Levee roadway has both visibility and ease of access as a transit-oriented development (TOD). Its relationship with the sidewalk and tideland promenade presents an opportunity for the design of public space.

The pier development on blocks oriented perpendicular to the Finger Levee roadway would be designed to accommodate the majority of the housing. The tideland habitat buffer shall determine the sizing and spacing of blocks, the density required in each site-specific development, and the space required for freshwater wetlands to recycle wastewater from adjacent buildings.
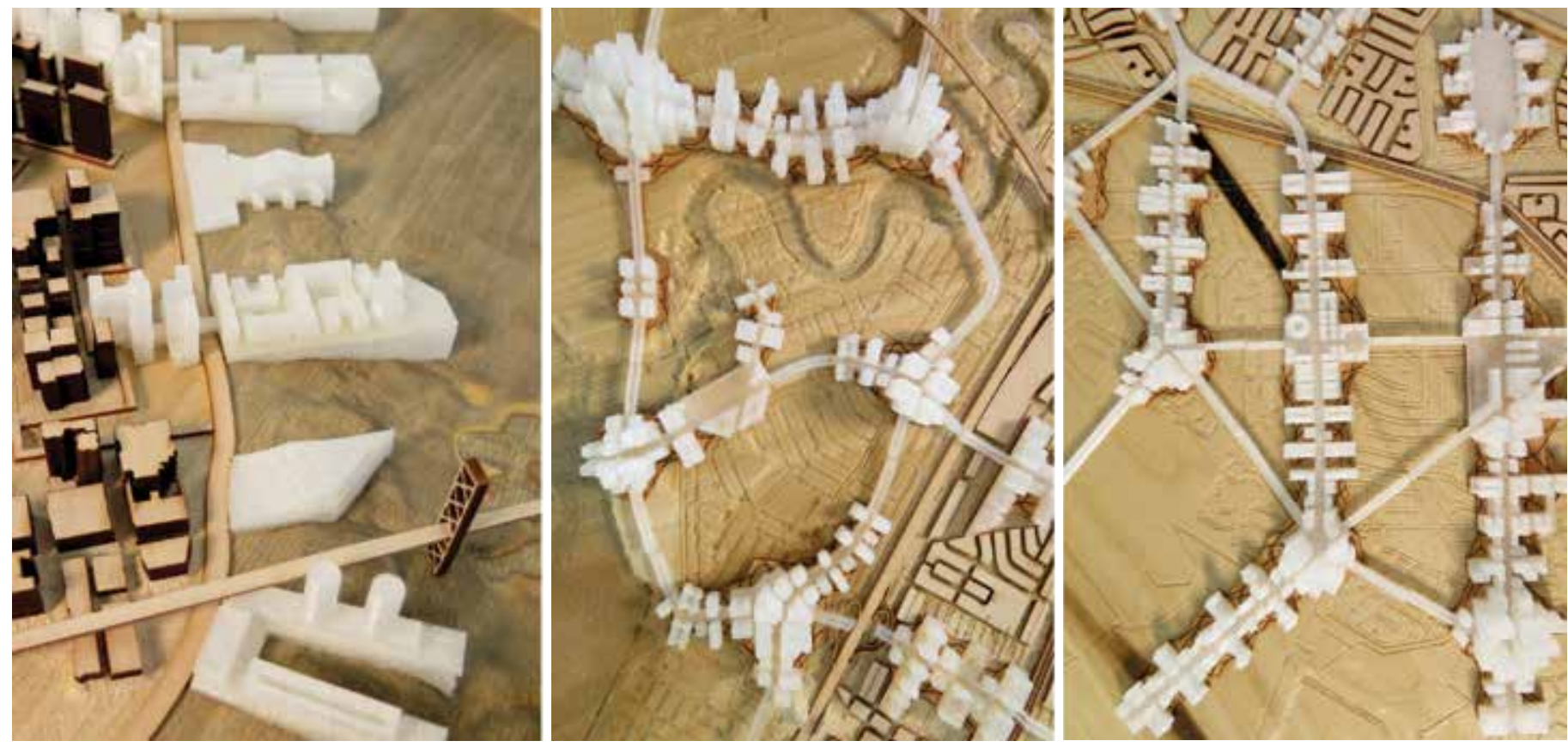

Figure 12. Physical model - close-up (left to right) San Francisco, San Mateo, Union City. 


\section{CONCLUSION}

The task of responding to sea-level rise in the Bay Area can seem a daunting proposal, but we should first begin by reframing the issue of sea-level rise as an opportunity to design better cities rather than a problem to be fixed. Perhaps, with this approach we can look beyond the current toolbox of planning, policy, and engineering that has lead to extensive development on bay fill, vulnerable to sea-level rise and flooding. Instead, we should be exploring new approaches to design our built environment along the Bay Shore, which strive for a mutually beneficial relationship with the tidal ecosystem, sustainable development practices, and community adaptation.

The design research presented here offers a framework for which to analyze past, present, and future conditions of sites at risk of sea-level rise around the San Francisco Bay for the purpose of creating a managed retreat and redevelopment strategy. This strategy aims to enable a wetland migration with the rising sea level, while introducing a resilient new development and infrastructure that is uniquely defined by the region's ecological characteristics. While I focused on three sites around the Bay, this design proposal is envisioned as a regional planning structure for all cities located on the perimeter of the San Francisco Bay. As a speculative design proposal, the goal is to create a constructive dialog. By imagining an alternative future and concretizing theory, we can begin to understand the potential implications of policy and design decisions. This work presents one model for an adaptive and resilient response to sea-level rise. However, I believe that an issue this complex will only be solved through interdisciplinary collaboration and community participation.
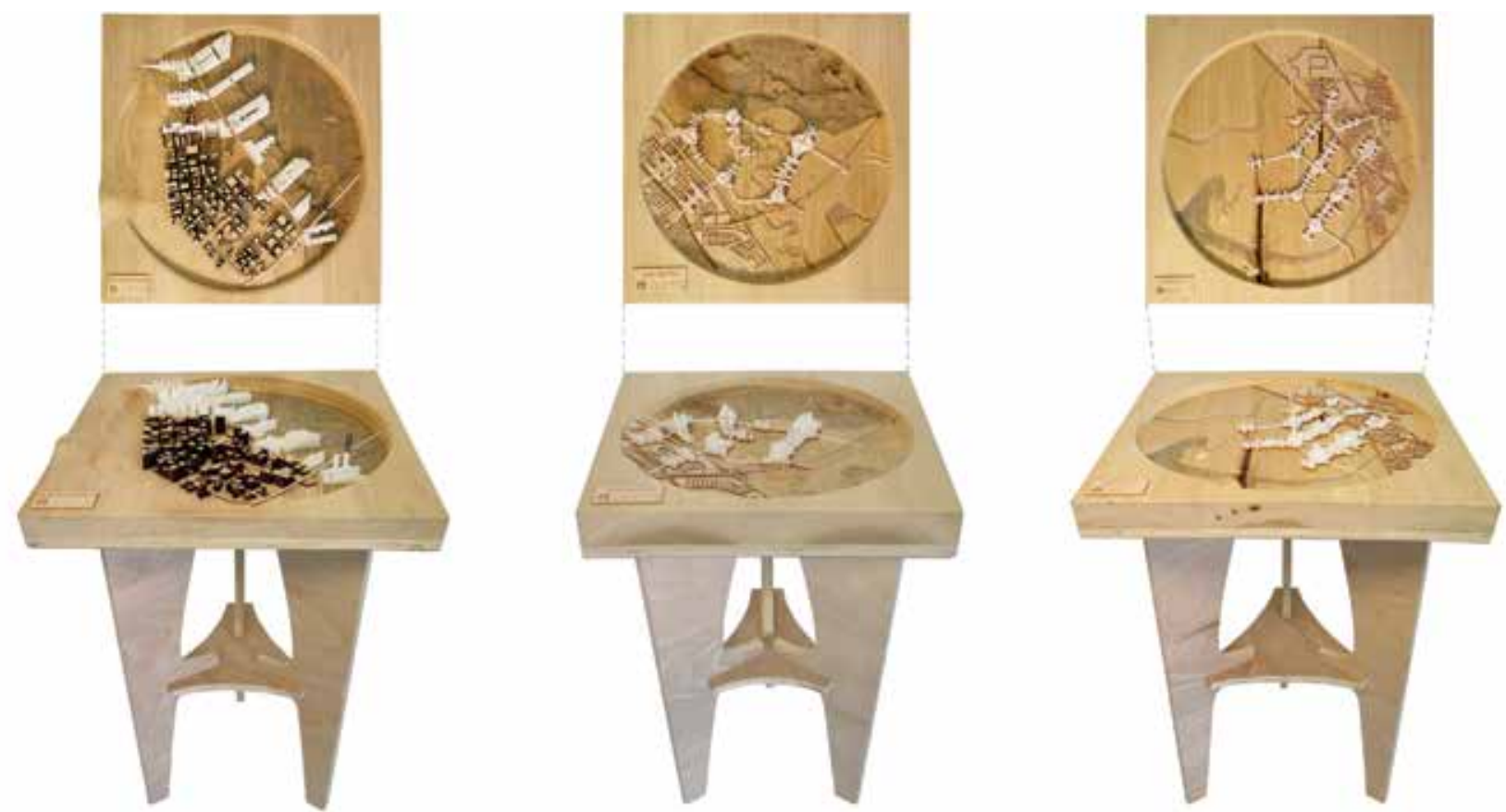

Figure 13. Physical model (left to right) San Francisco, San Mateo, Union City. 


\section{Notes}

1. Matthew Heberger and Pablo Herrera, "Needed Protection Structures:

The Impacts of Sea-Level Rise on the California Coast," in The Impacts of Sea-level Rise on the California Coast. A paper from the California Climate Change Center, ed. Matthew Heberger, Heather Cooley, Pablo Herrera, Peter H. Gleick, Eli Moore

(Oakland CA, USA: Pacific Institute, 2009).

2. San Francisco Bay Conservation and Development Comission (BCDC), Living with a Rising Bay: Vulnerability and Adaptation in San Francisco Bay and on its Shoreline, (2011), 80.

3. Virginia Burkett and Margaret Davidson, eds., Coastal Impacts, Adaptation and Vulnerability: A Technical Input to the 2013 National Climate Assessment (Chicago: Island Press, The National Oceanic and Atmospheric Administration, 2013), 7.

4. Id.

5. Matthew M. Booker, Down by the Bay: San Francisco's History Between the Bay

(Berkeley CA, USA, and Los Angeles: University of California Press, 2013), 19.

6. San Francisco Bay Conservation and Development Comission (BCDC), Living with a Rising Bay: Vulnerability and Adaptation in San Francisco Bay and on its Shoreline (2011), 79. http://www.bcdc.ca.gov/BPA/LivingWithRisingBay.pdf.

7. Burkett and Davidson, Coastal Impacts (2013), 57.

8. IPCC (Intergovernmental Panel on Climate Change), Strategies for Adaptation to Sea Level Rise. Report of the Coastal Zone Management Subgroup (WMO and UNEP: Geneva, 1990), 8.

9. FEMA, Levees: Information for Cooperating Technical Partners and Engineers (2014). https://www.fema.gov/living-levees-information-cooperating-technical-partners-and-engineers. 10. San Francisco Bay Conservation and Development Comission (BCDC). Resolution No. 11-08 Adoption of Bay Plan Amendment No. 1-08 Adding New Climate Change Findings and Policies to the Bay Plan; And Revising the Bay Plan Tidal Marsh and Tidal Flats; Safety of Fills; Protection of the Shoreline; and Public Access Findings and Policies (2011), 2. http://www.bcdc.ca.gov/proposed_bay_plan/10-01Resolution.pdf.

11. San Francisco Estuary Institute. "Historical Ecology" (2014). http://www.sfei.org/he 12. SLR stands for Sea Level Rise. It is a standard metric measurement in metres of the elevation or altitude of a location in reference to a historic mean sea level.

13. Mark Ruddock and D. Philip Whitfield, A Review of Disturbance Distance in Selected Bird Species. A report from Natural Research (Projects) Ltd to Scottish Natural Heritage (2007). http://www.snh.org.uk/pdfs/strategy/renewables/birdsd.pdf.

\section{References}

Brechin, Gray A. Imperial San Francisco: Urban Power, Earthly Ruin. Berkeley CA, USA, and Los Angeles: University of California Press, 2006.

Brewer, William H. Up and Down California 1860-1864. 3rd ed. by Francis P. Farquhar. Berkeley CA, USA: University of California Press, 1996.

Booker, Matthew M. Down by the Bay: San Francisco's History Between the Bay. Berkeley CA, USA, and Los Angeles: University of California Press, 2013.

Bosselmann, Peter. Urban Transformation Understanding City Design and Form. Washington, DC: Island Press, 2008.

- - Representation of Places Reality and Realism in City Design. Berkeley CA, USA: University of California Press, 1998.

Burkett, Virginia, and Margaret Davidson, eds. Coastal Impacts, Adaptation and Vulnerability: A Technical Input to the 2013 National Climate Assessment. Chicago: Island Press, The National Oceanic and Atmospheric Administration, 2012.

Cronon, William. "The Trouble with Wilderness: Or, Getting Back to the Wrong Nature." In Uncommon Ground: Toward Reinventing Nature, by William Cronon, 69-90. New York: W.W. Norton, 1995.

FEMA. Levees: Information for Cooperating Technical Partners and Engineers. 2014. https://www.fema.gov/living-levees-information-cooperating-technical-partners-and-engineers. 
Grossinger, Robin M. "Documenting Local Landscape Change: The San Francisco Bay Area Historical Ecology Project." In The Historical Ecology Handbook: A Restorationist's Guide to Reference Ecosystems. Edited by Dave Egan and Evelyn Howerll. Covelo CA, USA: Island Press, 2001.

Heberger, Matthew, and Pablo Herrera. "Needed Protection Structures: The Impacts of Sea-Level Rise on the California Coast." In The Impacts of Sea-level Rise on the California Coast. A paper from the California Climate Change Center. Edited by Matthew Heberger, Heather Cooley, Pablo Herrera, Peter H. Gleick, and Eli Moore. Oakland CA, USA: Pacific Institute, 2009. http://pacinst.org/wp-content/uploads/2014/04/sea-level-rise.pdf.

Hill, Kristina. "Climate-Resilient Urban Waterfronts." In Climate Adaptation and Flood Risk in Coastal Cities. Edited by Jeroen Aerts, Wouter Botzen, Malcom Bowman, Philip Ward and Piet Dircke. New York: Earthscan, 2012.

IPCC (Intergovernmental Panel on Climate Change). Strategies for Adaptation to Sea Level Rise. Report of the Coastal Zone Management Subgroup. WMO and UNEP: Geneva, 1990.

- -. Climate Change 2007: Impacts, Adaptation and Vulnerability. Contribution of Working Group II to the Fourth Assessment Report of the Intergovernmental Panel on Climate Change, edited by Martin L. Parry, Osvaldo F. Canziani, Jean P. Palutikof, Paul J. van der Linden and Clair E. Hanson. Cambridge, UK: Cambridge University Press, 2007.

- -. Contribution of Working Group III to the Fourth Assessment Report of the Intergovernmental Panel on Climate Change, edited by Bert Metz,

Ogunlade R. Davidson, Peter R. Bosch, Rutu Dave and Leo A. Meyer. Cambridge, UK and New York: Cambridge University Press, 2007.

King, John. "S.F. waterfront development must prepare for rising seas." SF Gate. June 8, 2014. http://www.sfgate.com/bayarea/place/article/S-F-waterfront-developmentmust-prepare-for-5536682.php.

Metcalf, Gabriel. "The Great Dithering." The Urbanist 532 (April 2014). http://www.spur.org/publications/article/2014-04-10/great-dithering.

Mostafavi, Moshen. Ecological Urbanism. Baden, Switz: Lars Müller Publishers, 2010.

Port of San Francisco. "Waterfront Land Use Plan Chapters." 2009. http://www.sfport.com/index.aspx?page=294.

- -. "10-Year Capital Plan: FY 2013-2022 Update." 2013. http://sfport.com/modules/showdocument.aspx?documentid=3463.

Rubin, Jasper. "San Francisco's Waterfront in the Age of Neoliberal Urbanism." In Transforming Urban Waterfronts: Fixity and Flow. Edited by Gene Desfor, Jennefer Laidley, Quentin Steves and Dirk Schubert. New York: Routledge, 2011.

Ruddock, Mark, and D. Philip Whitfield. A Review of Disturbance Distance in Selected Bird Species. A report from Natural Research (Projects) Ltd to Scottish Natural Heritage. 2007. http://www.snh.org.uk/pdfs/strategy/renewables/birdsd.pdf.

San Francisco Bay Conservation and Development Comission (BCDC). Living with a Rising Bay: Vulnerability and Adaptation in San Francisco Bay and on its Shoreline. 2011. http://www.bcdc.ca.gov/BPA/LivingWithRisingBay.pdf.

- -. Resolution No. 11-08 Adoption of Bay Plan Amendment No. 1-08 Adding New Climate Change Findings and Policies to the Bay Plan; And Revising the Bay Plan Tidal Marsh and Tidal Flats; Safety of Fills; Protection of the Shoreline; and Public Access Findings and Policies. 2011. http://www.bcdc.ca.gov/proposed_bay_plan/10-01Resolution.pdf.

San Francisco Estuary Institute. "Historical Ecology." 2014. http://www.sfei.org/he.

Solnit, Rebecca. Infinite City: A San Francisco Atlas. Berkeley CA, USA: University of California Press, 2010.

Spirn, Anne W. The Granite Garden: Urban Nature and Human Design. New York: Basic Books, 1984.

Stralberg, Diana, Matthew Brennan, John C. Callaway, Julian K. Wood, Lisa M. Schile, Dennis Jongsomjit, Maggi Kelly, V. Thomas Parker, and Stephen Crooks.

"Evaluating Tidal Marsh Sustainability in the Face of Sea- Level Rise: A Hybrid Modeling Approach Applied to San Francisco Bay." PLoS ONE 6, no.11 (November 2011). https://doi.org/10.1371/journal.pone.0027388.

Tam, Laura et al. "Climate Change Hits Home." SPUR Report. May 2011. http://www.spur.org/sites/default/files/publications_pdfs/SPUR_ClimateChangeHitsHome.pdf. 
Walker, Richard A., and William Cronon. The Country in the City: The Greening of the San Francisco Bay Area. Seattle WA, USA: University of Washington Press, 2007.

\section{Credits}

Figure 5: maps from David Rumsey Historical Map Collection. 1899 U.S. Geological Survey Map; 1852 U.S. Coast Survey Map; 1942 U.S. Geological Survey Map.

http://www.davidrumsey.com.

Figure 6: maps from David Rumsey Historical Map Collection.1899 U.S. Geological Survey Map. http://www.davidrumsey.com.

Gabriel Kaprielian is a designer, educator, and artist. His creative work and research are multi-scalar in approach and explore the intersections between resilient cities, sustainable design, emergent technologies, and digital fabrication. Gabriel is an Assistant Professor of Architecture at Temple University and Director of the Design and Innovation for Sustainable Cities program at the University of California Berkeley. He has previously taught at the California Polytechnic State University in San Luis Obispo CA, USA, and at the California College of the Arts in San Francisco. E-mail: Gabriel.Kaprielian@Temple.edu. 